\title{
PREFACE TO THE THIRD EDITION
}

Scholarship on the Syriac Bible does not stand still and so this third edition, provides the opportunity to take into account a number of important new developments, in particular the discovery of a third Old Syriac Gospel manuscript among the "New Finds" at the Monastery of St Catherine, Mount Sinai, and the appearance of the Gorgias Press's Antioch Bible, providing a new English translation of the entire Syriac Bible. Besides an updating of the Bibliography, a number of other small changes, corrections and additions have been made; thus, for example, in the section on the Psalms, a table has been added to indicate the differing divisions of the Psalter into bullale (East Syriac), marmyotho (West Syriac) and kathismata (Melkite).

Sebastian Brock

Oxford, August 2020 
